Volume 3

Issue 1 The Syriac Galen Palimpsest

Article 8

5-9-2019

\title{
The Textual Interest of the Syriac Versions of Galen's Simples
}

Irene Calà

Humboldt-Universität zu Berlin, annadalassena@gmail.com

Jimmy Daccache

Yale University, jimmy.daccache@yale.edu

Robert Hawley

École Pratique des Hautes Études, PSL, UMR8167, robert.hawley@cnrs.fr 


\title{
The Textual Interest of the Syriac Versions of Galen's Simples
}

\begin{abstract}
As a complement and supplement to the various articles in this issue devoted specifically to the manuscript olim Hiersemann 500/20, henceforth referred to as the "Syriac Galen Palimpsest", or simply "SGP", this article presents selected examples of how and why the undertext of SGP is important for scholarship, especially in disciplines beyond the confines of Syriac Christianity. Our examples are drawn from Sergius of Reš 'Aynä’s sixth century Syriac translation of Books VI-VIII of Galen of Pergamon's important pharmacological treatise On simple drugs (hereafter "Simples"), which, as is well known, is found not only in SGP, but also and especially in another, older and better preserved manuscript, British Library Additional 14661 (hereafter "BL"). These selected examples illustrate two points (both of which require much further study in order to be elucidated fully): firstly, how the Greek text of Galen's Simples, as published by Kühn, may in some cases be corrected on the basis of indirect textual evidence provided by Sergius' Syriac translation, and secondly, how Sergius' sixth century translation was to prove fundamental even centuries later, during the cAbbāsid translation movement centered in Baghdad.
\end{abstract}

\section{Keywords}

Greek, Syriac, Galen, Simples, On simple drugs, translation technique, textual criticism, Sergius of Rēš cAynā, Ḥunayn ibn Isḥāq 


\section{MANUSCRIPT STUDIES}

A Journal of the Schoenberg Institute for Manuscript Studies

VOLUME 3, NUMBER 1

(Spring 2018)

Manuscript Studies (ISSN 2381-5329) is published semiannually

by the University of Pennsylvania Press

The Schoenberg Institute
for Manuscript Studies
University of Pennsyivania Libraries 


\section{MANUSCRIPT STUDIES}

A Journal of the Schoenberg Institute for Manuscript Studies

VOL UME 3, N U M B E 1

Special Issue:

The Syriac Galen Palimpsest

Editors: William Noel and Ralph M. Rosen

\section{Articles}

The Syriac Galen Palimpsest Project: An Introduction

William Noel and Ralph M. Rosen

Pulling It All Together: Managing the Syriac Galen

Palimpsest Project

Michael B. Toth

The Codicology and Conservation of the Syriac

Galen Palimpsest

Abigail B. Quandt and Renée C. WolcotT

Spectral Imaging Methods Applied to the Syriac

Galen Palimpsest

Roger L. Easton, Jr., Keith T. Knox, William A. Christens-Barry, AND Ken Boydston

The Galen Palimpsest and the Modest Ambitions of the

Digital Data Set

Doug EMERY

The Syriac Galen Palimpsest: A Tale of Two Texts

Naima Afif, Siam Bhayro, Grigory Kessel, Peter E. Pormann,

William I. Sellers, and Natalia Smelova 
iv | Journal for Manuscript Studies

Analyzing Images, Editing Texts: The Manchester Project

Naima Afif, Siam Bhayro, Peter E. Pormann, William I. Sellers, and Natalia Smelova

The Textual Interest of the Syriac Versions of Galen's Simples

Irene Calà, Jimmy Daccache, and Robert Hawley 186

\section{Annotations}

Of Scribes and Scripts: Citizen Science and the Cairo Geniza

Preserving Endangered Archives in Jerba, Tunisia:

The al-Bāsī Family Library Pilot Project

Ali Boujdidi And Paul M. Love

The Intricacies of Capturing the Holdings of a Mosque

Library in Yemen: The Library of the Shrine of Imām alHādī, Șa da

Sabine Schmidtke

Compilation, Collation and Correction in the Time of Encyclopedism: The Case of UPenn LJS 55

Nathalie Lacarrière

Mapping Manuscript Migrations: Digging into Data for the History and Provenance of Medieval and Renaissance

Manuscripts

Toby Burrows, Eero Hyvönen, Lynn Ransom, and Hanno Wijsman

\section{Reviews}

Ahmad 'Abd al-Bāsit. Catalogue of the Private Collections of

Manuscripts in the Egyptian National Library

ELIAS G. SABA 
Manuscript Studies, Vol. 3 [2019], Iss. 1, Art. 8

Contents | v

David T. Gura. A Descriptive Catalogue of the Medieval and Renaissance Manuscripts of the University of Notre Dame and Saint Mary's College

LISA FAgin Davis 256

Christopher De Hamel. Meetings with Remarkable Manuscripts

Daniel Traister 260 
Calà et al.: The Textual Interest of the Syriac Versions of Galen's Simples 


\title{
The Textual Interest of the Syriac Versions of Galen's Simples
}

\author{
IRENE CAL À \\ Humboldt-Universität zu Berlin
}

JimMY DACCACHE

Yale University

ROBERT HAWLEY

École Pratique des Hautes Études, PSL, UMR 8167

S A COMPLEMENT AND supplement to the various articles in this
issue devoted specifically to the manuscript olim Hiersemann
$500 / 20,{ }^{1}$ henceforth referred to as the Syriac Galen Palimpsest
(SGP), ${ }^{2}$ this article presents selected examples of how and why this undertext

1 K. W. Hiersemann, Katalog 500: Orientalische Manuskripte (Leipzig: Hiersemann, 1922), no. 20, p. 13, pl. XI.

2 There is a growing secondary literature devoted to this manuscript. In addition to the contributions elsewhere in this volume (where further bibliography can be found), other previous studies include S. Bhayro, R. Hawley, G. Kessel, and P. E. Pormann, "Collaborative Research on the Digital Syriac Galen Palimpsest," Semitica et Classica 5 (2012): 261-64; S. Bhayro, R. Hawley, G. Kessel, and P. E. Pormann, "The Syriac Galen Palimpsest: Progress, Prospects and Problems," Journal of Semitic Studies 58 (2013): 131-48; S. Bhayro and S. Brock, "The Syriac Galen Palimpsest and the Role of Syriac in the Transmission of Greek Medicine in the Orient," Bulletin of the John Rylands University Library 89, Supplement (2013): 25-43; S. Bhayro and R. Hawley, "La littérature botanique et pharmaceutique en langue syriaque," in 
of the SGP is important for scholarship, ${ }^{3}$ especially in disciplines beyond the confines of Syriac Christianity. ${ }^{4}$ Our examples are drawn from the sixthcentury Syriac translation of Books 6-8 of Galen of Pergamon's important pharmacological treatise On Simple Drugs (hereafter Simples), as executed by Sergius of Reš 'Aynā, ${ }^{5}$ which, as is well known, is found not only in the SGP, but also and especially in another, older and better-preserved manuscript, British Library (BL) Add. MS 14661. ${ }^{6}$ These examples illustrate two points (both of which require much further scholarship in order to be elucidated fully): first, how the Greek text of Galen's Simples, as published by Kühn, ${ }^{7}$ may in some cases be corrected on the basis of textual evidence provided by

Les sciences en syriaque, ed. E. Villey, Études syriaques 11 (Paris: Geuthner, 2014), 285-318 at 293-299; R. Hawley, "More Identifications of the Syriac Galen Palimpsest," Semitica et Classica 7 (2014): 237-72; G. Kessel, "Membra disjecta sinaitica: A Reconstitution of the Syriac Galen Palimpsest," in Manuscripta Graeca et Orientalia: Mélanges monastiques et patristiques en l'honneur de Paul Gébin, ed. A. Binggeli, A. Boud'hors, and M. Cassin, Orientalia Lovaniensia analecta 243 (Leuven: Peeters, 2016), 469-96; N. Afif, C. Arsene, S. Bhayro, I. Calà, J. Daccache, R. Hawley, G. Kessel, P. E. Pormann, W. I. Sellers, and N. Smelova, "Continuing Research on the Syriac Galen Palimpsest: Collaborative Implementation Within the Framework of Two European Projects," Semitica et Classica 9 (2016): 261-68.

3 The overtext is also important; see, provisionally, Kessel, "Membra disjecta sinaitica," 471-72.

4 This study benefited from logistical and financial support provided by the ERC Floriental project (ERC-2010-StG-263783 Floriental) funded by the European Research Council's starting grant program, directed by R. Hawley and hosted by the French CNRS (UMR 8167 Orient and Méditerranée).

5 On the life and writings of Sergius, see E. Fiori, "Un intellectuel alexandrin en Mésopotamie: Essai d'une interprétation d'ensemble de l'œuvre de Sergius de Rēěśaynā," in De l'Antiquité tardive au Moyen Âge: Études de logique aristotélicienne et de philosophie grecque, syriaque, arabe et latine offertes à Henri Hugonnard-Roche, ed. E. Coda and C. Martini Bonadeo (Paris: Vrin, 2014), 59-90 (with anterior bibliography).

6 W. A. Wright, Catalogue of Syriac manuscripts in the British Museum acquired since the year 1838, part 3 (London: Trustees of the British Museum, 1872), 1187 (no. 1004). On this important manuscript, see also A. Merx, "Proben der syrischen Übersetzung von Galenus' Schrift über die einfachen Heilmittel," Zeitschrift der Deutschen Morgenländischen Gesellschaft 39 (1885): 237-305; S. Bhayro, "Syriac Medical Terminology: Sergius and Galen's Pharmacopia," Aramaic Studies 3 (2005): 147-65; I. Calà and R. Hawley, “Transliteration Versus Translation of Greek Plant Names in the Syriac Medical Writings of Sergius of Reš 'Aynā: On the Tables of Contents in BL Add. 14,661,” Aramaic Studies 17, no. 2 (2017): 155-82.

7 K. G. Kühn, Galeni opera omnia (Leipzig: Car. Cnoblochii, 1821-33), 20 vols. 
Sergius's Syriac translation, and second, how Sergius's sixth-century translation was to prove fundamental even centuries later, during the Abbasid translation movement centered in Baghdad. Other examples could be cited, ${ }^{8}$ of course, but it appears best in this context to present these as two clear illustrations of the textual interest of the Syriac translations of Galen's Simples.

\section{Sergius's Syriac Version Is Important for the Textual Criticism of the Greek Text of Galen}

The first example illustrates why and how the Syriac text of the BL manuscript and the SGP can be of considerable importance not only for Syriac studies, but also and even especially for specialists of Greek medical texts, since it sometimes allows one to propose or corroborate corrections to the Greek text of Galen's treatise On Simple Drugs. As is well known, scholars do not yet have at their disposal a modern critical edition of this Galenic treatise; the Greek text edited by Kühn, and published in the first half of the nineteenth century, is not entirely reliable, as Caroline Petit has shown. ${ }^{9}$

8 Some others were presented recently in Rome ("Were Sergius' Syriac Translations of Galen Good or Bad?," paper presented at the XII Simposium Siriaco \& X Congresso Studi arabo Cristiani, Pontificio Istituto Orientale-Collegio San Lorenzo da Brindisi, Roma, 19-24 August 2016), in Hamburg ("The Syriac Manuscript BL Add 14661 and the Greek text of Galen's Simples," paper presented at the international conference "Comparative Oriental Manuscript Studies: Looking Back-Looking Ahead,” Asien-Afrika-Institut, Universität Hamburg, 26 September 2016). These will be assembled and treated more fully in forthcoming publications, such as I. Calà, J. Daccache and R. Hawley, "La traduzione siriaca del trattato 'Sulle facoltà dei semplici' di Galeno: esempi di problemi testuali," article submitted for publication in the journal Galenos; and J. Daccache, "Traduction en syriaque," in the online Encyclopédie de l'humanisme méditerranéen, ed. H. Touati, at http://encyclopedie-humanisme .com/?Traduction-en-syriaque.

9 C. Petit, "La tradition manuscrite du traité des Simples de Galien. Editio princeps et traduction-annotée des chapitres 1 à 3 du livre I," in Histoire de la tradition et édition des médecins grecs-Storia della tradizione e edizione dei medici greci, Atti del VI Colloquio internazionale sull'ecdotica dei testi medici, Parigi aprile 2008, ed. V. Boudon-Millot, J. Jouanna, A. Garzya, and A. Roselli (Naples: D’Auria Editore, 2010), 143-65; C. Petit, "La tradition manuscrite du livre VI du traité des Simples de Galien," in Per l'ecdotica dei testi medici greci: 
Our example comes from the paragraph devoted to a plant called karpēsion in Greek, ${ }^{10}$ from Galen's Simples, Book 7, chapter 10, paragraph 14. The text as presented in Kühn's edition ${ }^{11}$ is provided below, followed by a provisional English translation; an asterisk follows the word that merits comment.

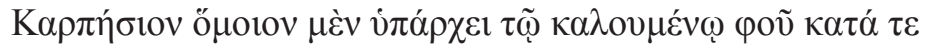

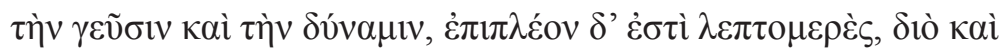

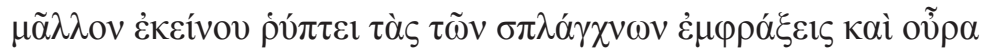

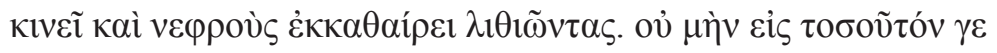

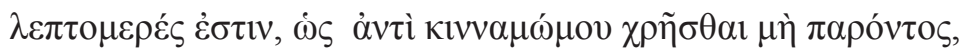

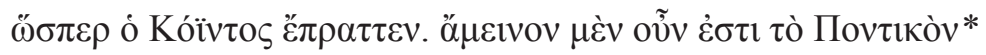

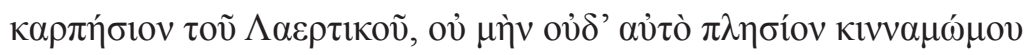

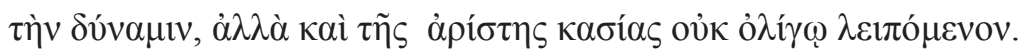

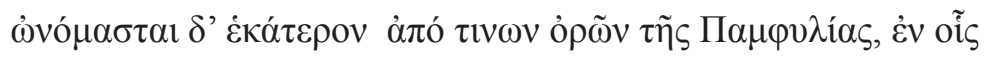

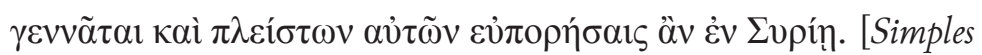
7.10.14 (XII.15.9-16.2 Kühn)]

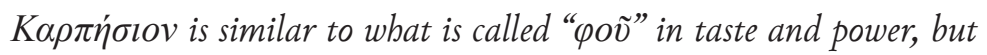
it is more attenuating, and for this reason it cleanses obstructions in the viscera more (than $\varphi$ ov does), stimulates urine, and purges kidneys that bave stones inside. Indeed, it is so attenuating that it is used instead of кıvvó $\mu \omega \mu$ ov, if (the latter) is not accessible, as Quintus used to do. Certainly the "Pontic" (kind of) $\kappa \alpha \rho \pi \dot{\sigma} \sigma l o v$ is better than the "Laertic" (kind), but it is certainly not closer to klvvó $\mu \omega \mu$ ov in power, but not a

VII Colloquio, Procida 11-13 giugno 2013, ed. V. Boudon-Millot, A. Ierci Bio, J. Jouanna, A. Roselli, and T. Raiola (Naples: D’Auria Editore, 2016), 115-34.

10 Modern students of Greek botanical terminology tend to agree that this phytonym refers to a species of valerian (sometimes specifically Valeriana Dioscoridis Sibth.; cf. J. André, Les noms de plantes dans la Rome Antique [Paris: Belles Lettres, 1985], 51), but it is interesting (and important) to note that Sergius himself was uncertain of the botanical meaning of the term; see Bhayro and Hawley, "La littérature botanique," 296, 304-6; Calà and Hawley, “Transliteration Versus Translation.”

11 Here and throughout, the abbreviation "Kühn" refers to the readily accessible and frequently cited edition of the Greek text of Galen's Simples: Kühn, Claudii Galeni opera omnia, vol. 11 (1826), 379-892; vol. 12 (1826), 1-377. 


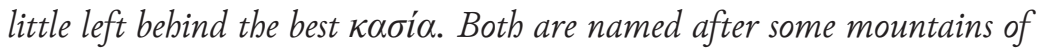
Pamphylia, in which it grows, but most of them you can find in Syria.

Of interest here is the phrase in which, according to Kühn's text, Galen states that the best kind of karpesion is the pontikon (variety-that is, Pontic, of the Pontus region). One finds the same reading (pontikon) in the Greek editions from the sixteenth century that preceded Kühn's edition: so, for example, in the Aldina edition published in $1525,{ }^{12}$ and in the Basel edition of $1538 .{ }^{13}$ We may also note that of the two Greek manuscripts considered by Caroline Petit to be the most reliable-namely, the manuscripts Vaticanus Urbinas graecus 67 (from the thirteenth century) and Vaticanus Palatinus graecus 31 (from the fourteenth century)-both transmit pontikon.

Moving on to the Latin translations of Galen, ${ }^{14}$ we also find ponticum, not only in the medieval Latin translation of Niccolò da Reggio, ${ }^{15}$ but also in those published during the Renaissance, such as that of Gerardus Gauda-

12 This first edition of the Greek text of Galen's opera omnia was published in Venice at the famous Aldine press: Galeni Librorum pars prima-quinta (Venice: Tipografia Aldina, 1525), five volumes; the chapter on carpesium is found in vol. 2:50r.

13 The second edition of the Greek text of Galen: Gemusaeus, Fuchsius \& Camerarius (eds.), Galeni Pergameni summi semper viri [. . .] Opera omnia, ad fidem complurium et perquam vetustorum exemplarium ita emendata atque restituta [. . . (Basel: Cratander, 1537), five volumes; the chapter on carpesium is in 2:89.

14 For a list of editions and translations of Galen published during the Renaissance, see R. J. Durling, "A Chronological Census of Renaissance Editions and Translations of Galen," Journal of the Warburg and Courtauld Institutes 24 (1961): 230-305; S. Fortuna, "Galeno e le sue traduzioni," Comunicare la cultura antica. I Quaderni del Ramo d'oro on-line 5 (2012): 112-22. See also the latter's online database: Catalogo delle traduzioni latine di Galeno, galenolatino.com.

15 This Latin translation was printed by Diomedes Bonardus in his Latin edition of Galen in two volumes (Venice: Filippo Pinzi, 1490); the translation of Niccolò da Reggio of this particular passage reads, "Melius autem est ponticum cubebe quam laerticum" (volume 2, n.p.). On the Latin translation of Niccolò, see C. Petit, "La tradition latine du traité des Simples de Galien: étude préliminare," Medicina nei Secoli, 25 (2013):1063-90; and for a general overview of Niccolò and his activity, see for example, V. Nutton, "Niccolò in context," Medicina nei Secoli 25 (2013): 941-56. 
nus, published in Paris in $1530,{ }^{16}$ that of Janus Cornarius published in $1549,{ }^{17}$ and that of Agostino Gadaldini published in $1565 .{ }^{18}$ In all of these Latin translations, one finds ponticum for this passage.

However, if one looks at the late antique compilers, such as Oribasius, one finds, in the corresponding paragraph of his Medical collections (Collectiones medicae), ${ }^{19}$ the following:

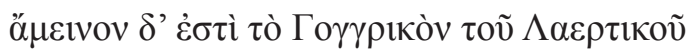

16 T. G. Gaudanus (Paris: Apud Simonem Colineum, 1530), 159, for the chapter on carpesium, with the phrase "praestantius est ponticum carpesium laertio." On Gaudanus and his translations, see C. Petit, "La tradition latine," and I. Calà, "Theodoricus Gerardus Gaudanus traduttore di Galeno,” Medicina nei Secoli 25 (2013): 1091-102.

17 J. Cornarius, Galeni Pergameni asiani, excellentissimi semper, post unicum Hippocratem, medici ab omnibus habiti opera quae ad nos extent omnia, [. . .] a viris doctissimis in Latinam linguam conversa [. . .] (Basel: Froben, 1549), 9 vols.; see 5:194-95 for this passage on carpesium ("praestantius est ponticum carpesium laertio"). Janus Cornarius was a very famous translator of Galen, perhaps even the most famous; among many articles, one can cite A. Guardasole, "Janus Cornarius éditeur et commentateur du traité de Galien 'Sur la composition des médicaments selon les lieux," Renassaince and Reformation/Renaissance et Réforme 33, no. 3 (special issue: De Fabrica Artis Medicina: Les redéfinitions de la médecine à la Renaissance, 2010): 85-97.

18 A. Gadaldini, Galeni omnia quae extant opera (Venice: Apud Iuntas, 1565), 11 volumes; this passage on carpesium is in 6:50r ("praestantius est Ponticum carpesium Laertio"). Gadaldini was an important scholar; see I. Garofalo, "Agostino Gadaldini (1515-1575) et le Galien latin,” in Lire les médecins grecs à la Renaissance, ed. V. Boudon-Millot and G. Cobolet (Paris: Éditions de Boccard, 2004), 284-321; C. Petit, “Gadaldini's Library," Mnemosyne 60 (2007): 132-38.

19 For the Greek text of Oribasius, Collectiones medicae, book XV, chapter 1.10, sections 26-27, see J. Raeder, Oribasii collectionum medicarum reliquiae, vol. 2, Corpus medicorum Graecorum 6.1.2 (Leipzig: Teubner, 1929): 257, 12-16. Cf. the French translation of this passage (Daremberg's Greek text is virtually the same as that of the Raeder edition) from U. C. Bussemaker and Ch. Daremberg, eds., Euvres d'Oribase : texte grec, en grande partie inédit, collationné sur les manuscrits, traduit pour la première fois en français . . ., vol. 2 (Paris: Imprimerie nationale 1854), 645, 2-7: "Le carpesium ressemble à ce qu'on appelle valériane, aussi bien sous le rapport du goût que sous celui des propriétés, cependant il est plus subtil, mais il ne l'est pas à un tel degré, qu'on puisse l'employer à la place de la cannelle, comme le

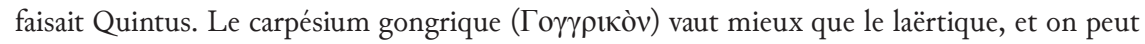
se procurer ces médicaments dans la plus grande abondance à Sidé.” 
The "Gongric" (Гоүурiкòv) (type of carpesion) is better than the "Laertic" (type).

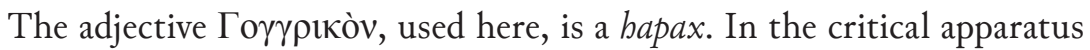
of Raeder's edition, the editor notes that in one manuscript (Parisinus grae-

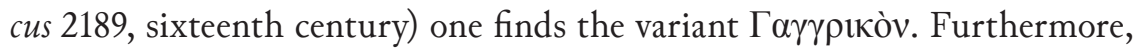
in some manuscripts of another late antique compiler, Aetius of Amida, ${ }^{20}$ we find in Book 1, at the end of the section devoted to the letter kappa, some three additional unnumbered chapters, one of which is this paragraph devoted to karpesion. There the adjective we are interested in is written

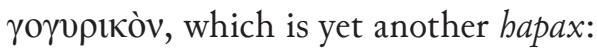



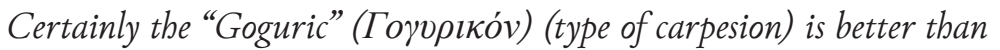
the "Laertic" (type).

Thus far, this survey of the textual evidence for this passage in Galen's Simples suggests that the word pontikon in this passage, as transmitted not only in the Greek manuscript tradition but also in the Latin translations, appears, when compared with the evidence of the late antique medical compilers, to be corrupt: a simpler and more common adjective (pontikon) has been introduced into the manuscript tradition in the course of its transmission, replacing a rarer or more obscure adjective. Thus, applying the text critical principle of lectio difficilior potior, we can infer that the late antique medical compilers Oribasius and Aetius probably preserve echos of the correct lectio.

20 The Greek text is reprinted from A. Olivieri, Aëtii Amideni libri medicinales, vol. 1, Corpus

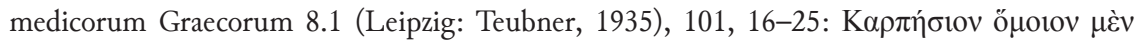

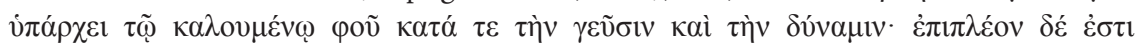



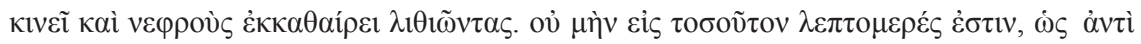

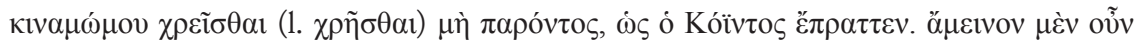

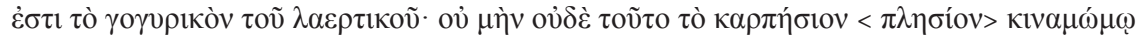

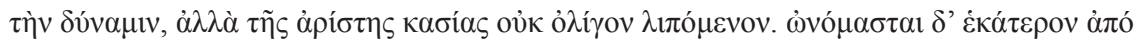

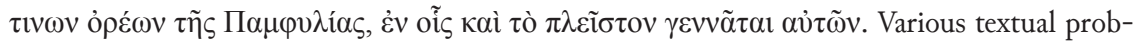
lems in this passage were discussed by I. Calà, "Per l'edizione del primo dei 'Libri medicinales' di Aezio Amideno," Ph.D. dissertation (University of Bologna, 2012), 159-60. 
And yet no fewer than three different Greek variants are attested for this passage in the late antique medical treatises that made extensive use of

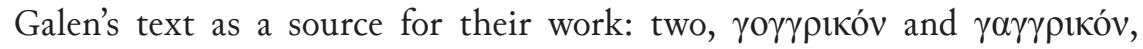

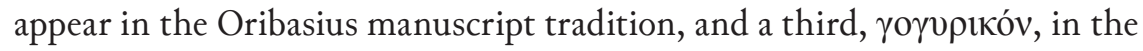
Aetius manuscript tradition. Thus, given this diversity, even if these traditions preserve echoes of the correct lectio here, some further corruptions have obviously been introduced.

It is in this context that the evidence from the Syriac tradition becomes important. In the first place, the Syriac translation of Sergius of Reš 'Aynā (in the BL manuscript and the SGP) is of great interest chronologically, since the manuscripts themselves are very early. The BL manuscript has been dated paleographically to the sixth or seventh century (that is, more than five centuries earlier than the earliest extant Greek manuscripts of Galen), ${ }^{21}$ and the SGP perhaps to the ninth century, ${ }^{22}$ which is still remarkably early with respect to the other manuscript witnesses to Galen's text.

Second, the Syriac witness is of great textual interest. The passage with which we are concerned is preserved not only in the very legible BL manuscript (see fig. 1), but also in the SGP (see fig. 2).

The passage in question is most easily legible in the BL manuscript. In lines $15-16$ of fol. $37 \mathrm{v}$, we read:

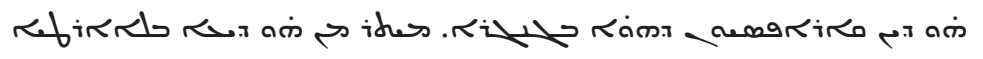

That (kind of) * $\kappa \alpha \rho \pi \dot{\sigma} \sigma l o v^{23}$ that exists in Gangra ${ }^{24}$ is better than the one that grows in Laertia [sic]

21 Wright, Catalogue, 1187: "written in a good, regular Esțrangĕlā of the vith or viith cent." 22 See Bhayro and Brock, “The Syriac Galen Palimpsest," 26.

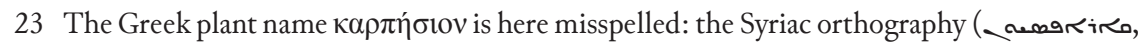

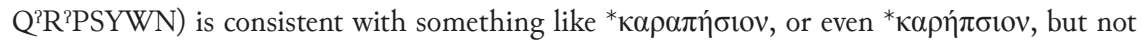

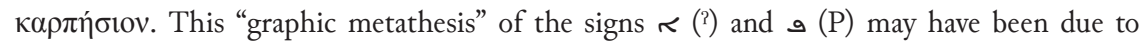
copyist error, or it may reflect a nonstandard pronunciation of the Greek phytonym in a Syriac scholarly context.

24 In the absence of other data, several theoretically plausible vocalizations for this orthography could be imagined, such as ${ }^{*}$ Gengrā or (as above) Gangrā. We obviously favor the latter based on the evidence from Greek texts and coins (see note 26). Note also that the Syriac 


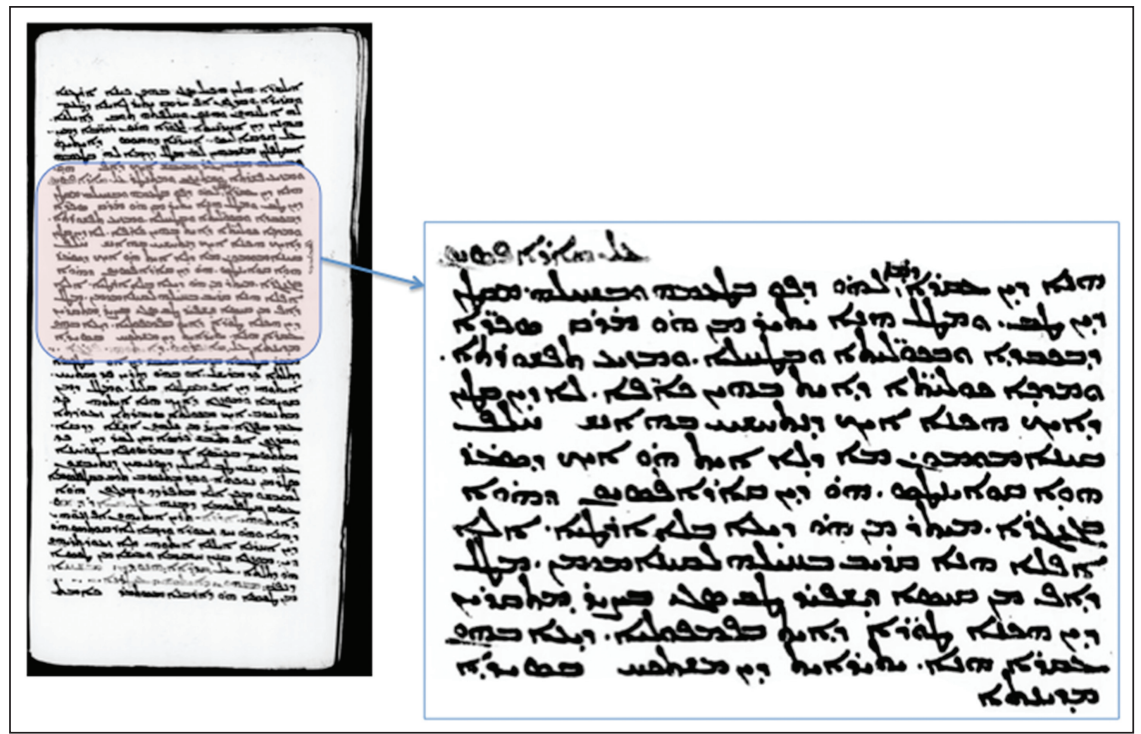

FIGURE 1. Folio 37v of BL Add MS 14661, with detail of lines 8-21. (C) British Library Board (Add. MS 14661).

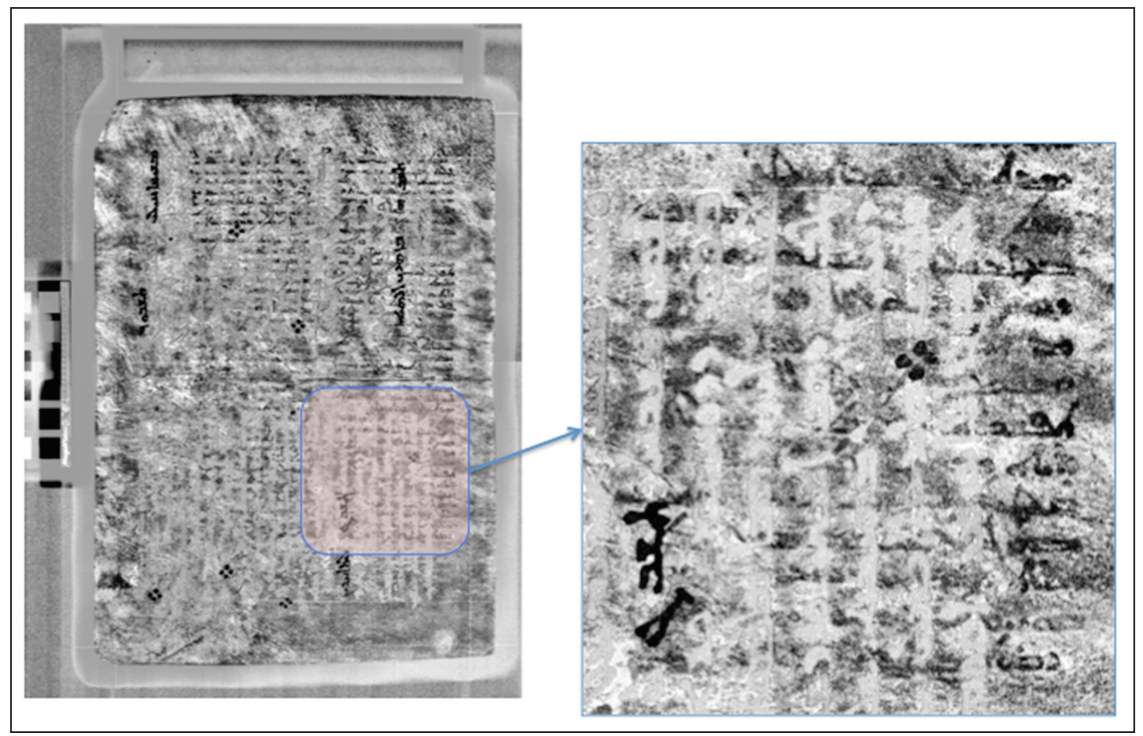

FIGURE 2. Bifolium 159v-162r of the Syriac Galen Palimpsest, with detail of column A, lines 24-37. (C) Owner of the Syriac Galen Palimpsest Creative Commons Attribution 3.0 Unported Access Rights. 


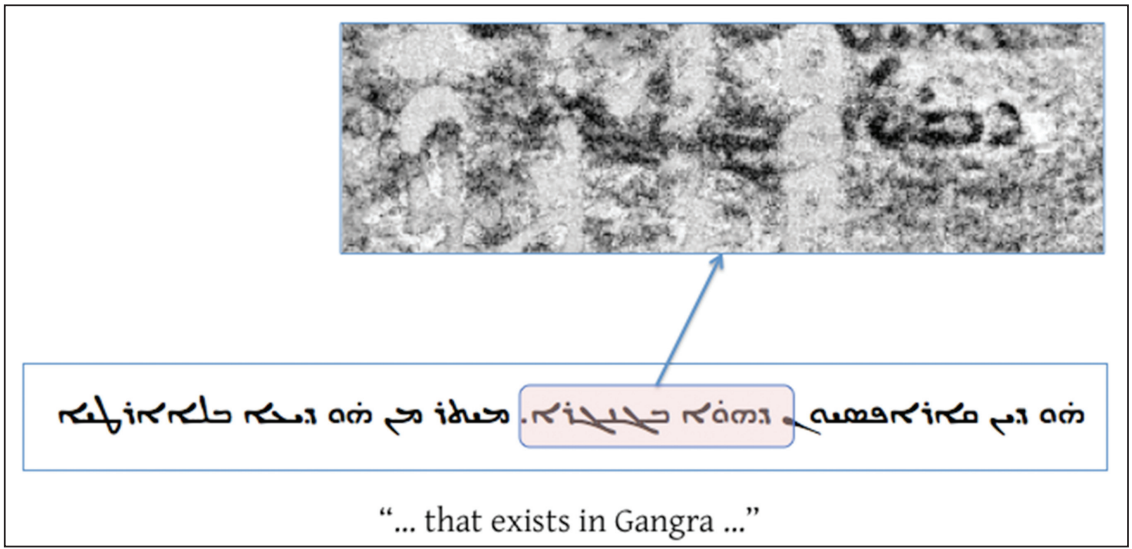

FIGURE 3. Detail of column A, line 37, from bifolium 159v-162r of the Syriac Galen Palimpsest. (C) Owner of the Syriac Galen Palimpsest, Creative Commons Attribution 3.0 Unported Access Rights.

The SGP is not quite as clear at this point, but thanks to the distinctive silhouette of the gammel signs (extending well below the base line), we can be quite sure that the SGP also had gangrā (see fig. 3).

Thus, according to Sergius's version of this text, there are two kinds of

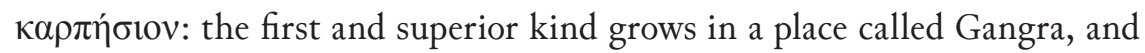
the second in a place called Laertia. We clearly have two different toponyms.

Laerte $(\mathrm{s})^{25}$ is a city in Cilicia in today's southern Turkey. ${ }^{26}$ The other toponym, written (that is, GNGR? ${ }^{2}$ ) in Syriac characters, must

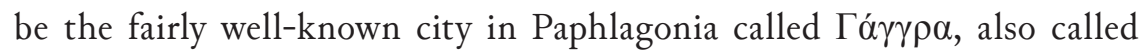

orthography is phonetic, representing the Greek velar nasal (written - $\gamma \gamma$ - in $\Gamma$ ó $\gamma \gamma \rho \alpha$ ) as - $\boldsymbol{乙}^{-}$ (that is, -NG-); cf. A. M. Butts, Language Change in the Wake of Empire: Syriac in Its Greco-Roman Context, Linguistic Studies in Ancient West Semitic 11 (Winona Lake, PA: Eisenbrauns, 2016), 86.

25 The Syriac orthography ( or copyist mistakenly assimilated this place name to the common toponymic pattern ending in $-i a$.

26 G. E. Bean and T. B. Mitford, "Sites New and Old in Rough Cilicia," Anatolian Studies 12 (1962): 194-96; Bean and Mitford, Journeys in Rough Cilicia, 1964-1968 (Vienna: Böhlau, 1970), 94-105. 
Germanikopolis or Germanikopolis by Gaggra or Gaggrois, and which has apparently left an echo in the modern Turkish city name of Çankırı. ${ }^{27}$

Finally, in certain late medical texts we also find mention of a kind of

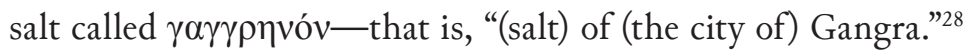

As intimated above, the lectiones transmitted by the Greek and Latin manuscript traditions of Galen, namely Pontic (pontikon, ponticum), seem best explained as reflections of a lectio facilior. The lectio transmitted by

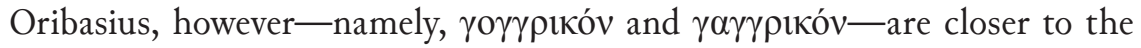
attested late adjective Г $\alpha \gamma \gamma \rho \eta v o ́ v$ (of Gangra). The transformations undergone in the Oribasius manuscipt tradition are thus probably copyists' mistakes.

$$
\begin{aligned}
& \text { Gangrenon } \rightarrow \text { Gongrenon } \rightarrow \text { Gongrinon } \rightarrow \text { Gongrikon } \\
& \text { Gangrenon } \rightarrow \text { Gangrinon } \rightarrow \text { Gangrikon }
\end{aligned}
$$

It appears legitimate to us to emend Galen's Greek text in the following way:

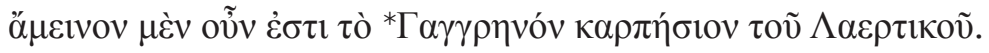

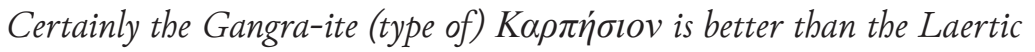
(type).

The Syriac witness in this case is a fundamental argument in favor of incorporating such a textual emendation into the critical edition of the Greek text.

27 L. Robert, À travers l'Asie Mineure: poètes et prosateurs, monnaies Grecques, voyageurs et géographie, Bibliothèque des Écoles françaises d'Athènes et de Rome 239 (Paris: de Boccard, 1980), 203-19; see also Der Neue Pauly. Enzyklopädie der Antike (Stuttgart-Weimar: Verlag J. B. Metzler, 1998), 4:777; and S. Giftopoulou, “Gangra (Byzantium)," Encyclopaedia of the Hellenic World, Asia Minor, http://www.ehw.gr/l.aspx?id=7515.

28 For example, Demetrius Pepagomenus, Iatrikon, 42 = ed. Capone Ciollaro (2003), p. 70,15-16; see also B. Zipser, John the Physician's “Therapeutics": A Medical Handbook in Vernacular Greek (Leiden: Brill, 2009), 160-61. 


\section{The Two Syriac Versions Are Important for the Study of Translation Technique}

Another example of the textual interest of the Syriac versions of Galen's Simples concerns not only Sergius's sixth-century Syriac translation, but also and especially comparison of the former with the later ninth-century translation of the same work done by the famous Syro-Arabic scholar of Abbasid Baghdad, Hunayn ibn Ishāq. ${ }^{29}$ Hunayn's Arabic translation of Galen's Simples has been known for some time, ${ }^{30}$ while his Syriac version of the same treatise remains less well known. ${ }^{31}$

Hunayn's Syriac version of the Simples is less well known mostly because it has not survived intact: what has survived is only a collection of isolated fragments. The fragments are distributed throughout a larger compendium also compiled by Hunayn, but devoted specifically not to simple remedies but instead to the properties of foodstuffs. ${ }^{32}$ As his main source in assembling this compilation, Hunayn naturally used Galen's treatise On the Properties of

29 On the life and writings of Hunayn, see J. C. Lamoreaux, Hunayn ibn Isp̣āq on His Galen Translations: A Parallel English-Arabic Text, Eastern Christian Texts 5 (Provo, UT: Brigham Young University Press, 2016), xii-xviii (with extensive bibliography).

30 Recent surveys of the Arabic tradition of Galen's Simples (with discussion and further bibliography) include M. Ullmann, Wörterbuch zu den griechisch-arabischen Übersetzungen des 9. Jabrbunderts (Wiesbaden: Harrassowitz Verlag, 2002), 15-48; and P. E. Pormann, "The Development of Translation Techniques from Greek Into Syriac and Arabic: The Case of Galen's on the Faculties and Powers of Simple Drugs, Book Six," in Medieval Arabic Thought: Essays in Honour of Fritz Zimmermann, ed. R. Hansberger, M. Afifi al-Akiti, and C. Burnett (London: Warburg Institute, 2012), 143-62 at 146-47.

31 Provisionally, see Bhayro et al., "Collaborative Research,” 264; Bhayro et al., "Progress, Prospects and Problems," 139-43; Bhayro and Hawley, "La littérature botanique," 300-302. 32 The preliminary, pioneering work on this treatise was done in the 1970s by R. Degen: see, for example, his “Ein Corpus Medicorum Syriacorum,” Medizinbistorisches Journal 7 (1972): 114-22 at 119-20; further bibliography is listed in R. Hawley, "Preliminary Notes on a Syriac Treatise About the Medicinal Properties of Foodstuffs," Semitica et Classica 1 (2008): 81-104 at 81 (and nn. 2-3); Hawley, "Three Fragments of Antyllus in Syriac Translation," in Sur les pas des Araméens chrétiens: Mélanges offerts à Alain Desreumaux, ed. F. Briquel-Chatonet and M. Debié, Cahiers d'études syriaques 1 (Paris: Geuthner, 2010), 241-56 at 242-43; Bhayro and Hawley, "La littérature botanique," 299-303; and G. Kessel, "Appendix 4: Inventory of Galen's Extant Works in Syriac,” in Lamoreaux, Hunayn ibn Ishāa q, 168-92 at 174-75. 
Foodstuffs, but to this he added extracts of various other works and even other authors, as he judged appropriate, including extracts taken from Galen's Simples. ${ }^{33}$

The textual interest of these fragments lies in the fact that they allow one to compare these selected passages of Hunayn's ninth-century translation with their parallel counterparts in the earlier translation of Sergius executed three centuries earlier. The reason that this is interesting is that it allows one to assess, in an empirical way and on the basis of tangible examples, not only how translation techniques had changed over the course of three centuries, ${ }^{34}$ but also and especially how particular translators worked, and how they interacted with the work of their predecessors. ${ }^{35}$ This is important because Hunayn, in his auto-biographical Risāla, ${ }^{36}$ was often rather critical of the (allegedly) poor quality of the translations produced by

33 An idea of the contents can be gained from perusing the summary given in Hawley, "Preliminary Notes," 88-96.

34 The study of Syriac translation techniques has a considerable bibliography. In addition to the pioneering work of Sebastian Brock (conveniently, see S. P. Brock, "Changing Fashions in Syriac Translation Technique: The Background to Syriac Translations Under the Abbasids," Journal of the Canadian Society for Syriac Studies 4 [2004]: 3-14; references to Brock's previous work on the subject may be found in the endnotes), other recent examples (with much additional bibliography) include D. King, The Syriac Versions of the Writings of Cyril of Alexandria: A Study in Translation Technique (Louvain: Peeters, 2008); the studies of A. McCollum, "Sergius of Reshaina as Translator: The Case of the De Mundo," and of E. Fiori, "Sergius of Reshaina and Pseudo-Dionysius: A Dialectical Fidelity," both in Interpreting the Bible and Aristotle in Late Antiquity: The Alexandrian Commentary Tradition Between Rome and Baghdad, ed. J. Lössl and J. W. Watt (Farnham: Ashgate, 2011), 165-78 and 179-94, respectively; and J. Daccache, "La traduction en syriaque."

35 For other examples of such an approach, see the bibliography and comparative study of Pormann, “The Development of Translation Techniques," 145 n. 11, 148-57.

36 The classic publication is G. Bergsträsser, Hunain ibn Ishāq über die syrischen und arabischen Galen-Übersetzungen, Abhandlungen für die Kunde des Morgenlandes XVII/2 (Leipzig: Deutschen Morgenländischen Gesellschaft, 1925); see also M. Meyerhof, "New Light on Hunain Ibn Ishâqq and His Period," Isis 8 (1926): 685-724; G. Bergsträsser, Neue Materialen zu Hunain ibn Ishạaq's Galen-Bibliographie, Abhandlungen für die Kunde des Morgenlandes XIX/2 (Leipzig: Deutschen Morgenländischen Gesellschaft, 1933); more recently, F. Käs, "Eine neue Handschrift von Hunain ibn Ishāqs Galenbibliographie," Zeitschrift für Geschichte der arabisch-islamischen Wissenschaften 19 (2010-11): 135-93; and especially Lamoreaux, Hunayn ibn Ishạa, with a new translation, discussion, and extensive bibliography. 
his predecessors, and by Sergius in particular. ${ }^{37}$ Thus, by comparing and studying actual parallel examples of the same passage in the translations of Sergius and of Hunayn, respectively, one can better nuance and evaluate the accuracy of Hunayn's statements.

Of the several dozen fragments of Hunayn's Syriac translation of Galen's Simples, ${ }^{38}$ which are of varying length and dispersed among various passages throughout his compilation On Foodstuffs, we have here selected a single fragment to present in this particular context, since it illustrates well two important types of Hunayn's translation techniques. The example is an excerpt from Book 7 of Galen's Simples, chapter 10 (plant names beginning with the letter $\kappa \alpha \pi \pi \alpha$ ), paragraph 20 , devoted to the carob tree and its fruits, carob pods. ${ }^{39}$ A glance at the Greek source text (see table 1) shows that Galen is here making a distinction between the different therapeutic effects of carob pods, depending on whether they are dehydrated or not.

As one can see, the basic idea conveyed in this passage is that fresh carob pods are laxative, but dried carob pods constipating; in the passage that immediately follows, Galen tries to explain and substantiate such a polar distribution of therapeutic properties on the basis of elemental theory.

Turning to the two extant Syriac renderings of this passage, we may begin our comparison by examining first the earlier one, ${ }^{40}$ executed in the sixth century by Sergius of Reš 'Aynā (see table 2).

The present summary article is hardly the occasion to dissect and analyze in detail Sergius's translation technique. For the sake of expediency, suffice it to say that Sergius's translation of this passage is, though quite literal, not slavishly so. Note, for example, the omission of the second adverbial $\mu \tilde{\alpha} \lambda \lambda$ ov in segment [4], since such was probably clear from the

37 Cf., for example, Brock, "Changing Fashions," 8-9; see also Bhayro and Brock, "The Syriac Galen Palimpsest,” 41-42.

38 The present authors are preparing a study in which the whole corpus of these fragments is presented and discussed.

39 That is, Simples 7.10.20 (XII 23, 12-15 Kühn).

40 Indeed, not merely "earlier" but perhaps even "earliest," if we are to trust the testimony of the famous thirteenth-century scholar Bar Hebraeus, who reports that it was Sergius "who first translated medical texts from Greek into Syriac"; see Bhayro, "Syriac Medical Terminology," 153. 
TABLE 1. A segmented, tabular presentation of the Greek text of Galen's Simples VII.10.20 (XII.23, 12-15 Kühn).

\begin{tabular}{|c|c|c|}
\hline $\begin{array}{l}\text { Arbitrary } \\
\text { segment } \\
\text { number }\end{array}$ & Greek source text* & English translation ${ }^{* *}$ \\
\hline [1] & 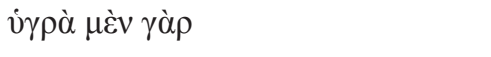 & for (when) moist, \\
\hline [2] & 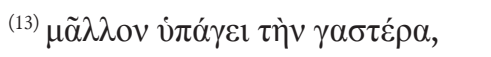 & it discharges the belly more, \\
\hline [3] & $\xi \eta \rho \grave{~} \delta$ & but (when) dry, \\
\hline [4] & 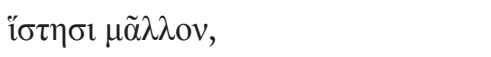 & it stops (the belly) more, \\
\hline$[5]$ & 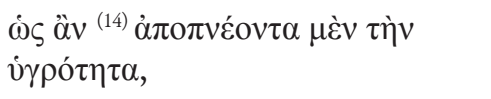 & $\begin{array}{l}\text { such that, having excreted } \\
\text { the moisture, }\end{array}$ \\
\hline [6] & 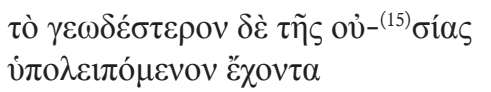 & $\begin{array}{l}\text { (that which) has a more } \\
\text { earthy substance remains }\end{array}$ \\
\hline
\end{tabular}

* As per Kühn XII.23, 12-15.

** The translation is voluntarily overly literal, in order best to illustrate how Sergius's and Hunayn's techniques compare with each other and with the Greek source. Elements in parentheses are implied from context (but not explicitly present lexically in the source text).

preceding context. Taken as a whole, the rendering of this passage appears to be a quite comprehensible, quite grammatically sound translation. In the Pseudo-Dionysian corpus, Emiliano Fiori had evoked Sergius's “intelligent, but never slavish, fidelity to the original"11_-such a characterization seems to the present authors to apply here also quite well.

Turning now to Hunayn's rendering of the same passage, one may notice both similarities and differences with respect to Sergius's earlier version (see table 3).

The most impressive similarities show up in segments [4]-[6]: indeed the two Syriac versions are identical. If we were to typologize Hunayn's method of interaction with Sergius's earlier translation in his own work, we might profitably distinguish three broad "types" of approach. The first, which we might humorously characterize as the "copy-paste" approach, is

41 Fiori, "Sergius of Reshaina," 179. 
TABLE 2. A segmented, tabular presentation of Sergius's sixth-century Syriac rendering of Galen's Simples VII.10.20 (XII.23, 12-15 Kühn).

\begin{tabular}{|c|c|c|c|c|}
\hline & Greek source text & & Sergius's Syriac rendering* & $\begin{array}{l}\text { English translation of } \\
\text { the Syriac** }\end{array}$ \\
\hline [1] & 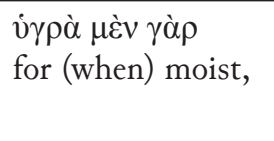 & $\rightarrow$ & 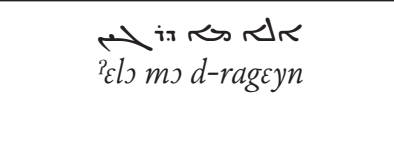 & $\begin{array}{l}\text { however, when (they) are } \\
\text { moist, }\end{array}$ \\
\hline [2] & 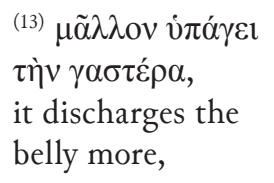 & $\rightarrow$ & 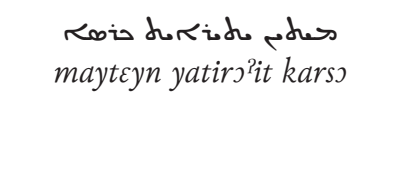 & $\begin{array}{l}\text { they loosen to a greater } \\
\text { degree the belly, }\end{array}$ \\
\hline [3] & 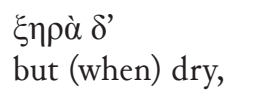 & $\rightarrow$ & mod-yabišin deyn & but when (they) are dry, \\
\hline [4] & $\begin{array}{l}\text { ĩ } \sigma \tau \eta \sigma \iota \mu \tilde{\alpha} \lambda \lambda \mathrm{ov}, \\
\text { it stops (the belly) } \\
\text { more, }\end{array}$ & $\rightarrow$ &  & $\begin{array}{l}\text { they bring it (= the belly) } \\
\text { to a standstill, }\end{array}$ \\
\hline$[5]$ & 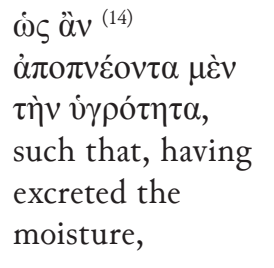 & $\rightarrow$ & 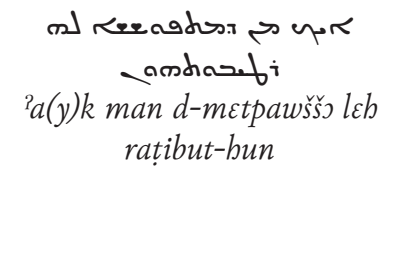 & $\begin{array}{l}\text { such that their humidity } \\
\text { is excreted by it (= the } \\
\text { carob pod), }\end{array}$ \\
\hline [6] & 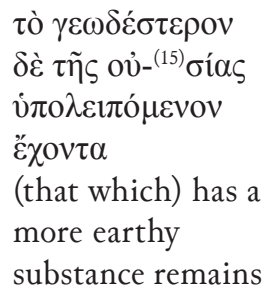 & $\rightarrow$ & 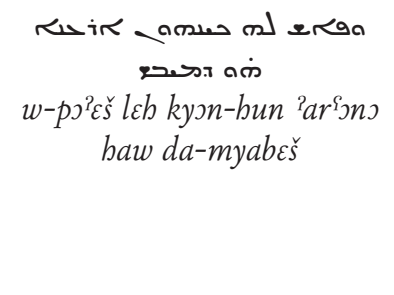 & $\begin{array}{l}\text { and (what) remains to it } \\
\text { (is) their earthy substance, } \\
\text { which dries }\end{array}$ \\
\hline
\end{tabular}

\footnotetext{
* As per BL Add. MS 14661, lines 30-33; and SGP 200r-201v, col. B, lines 12-17 (provisionally see R. Hawley, "More Identifications of the Syriac Galen Palimpsest," Semitica et Classica 7 [2014]: 237-72 at 253 and 262 [figs. 44-45]; cf. also the "skeleton table" in N. Afif, C. Arsene, S. Bhayro, I. Calà, J. Daccache, R. Hawley, G. Kessel, P. E. Pormann, W. I. Sellers, and N. Smelova, "Continuing Research on the Syriac Galen Palimpsest: Collaborative Implementation Within the Framework of Two European Projects," Semitica et Classica 9 [2016]: 261-68 at 267).

** On the excessively literal nature of this translation, see table 1 , note ${ }^{* *}$.
} 
TABLE 3. Sergius's sixth-century and Hunayn's ninth-century Syriac renderings of Galen's Simples VII.10.20 (XII.23.12-15 Kühn).

\begin{tabular}{|c|c|c|c|c|c|}
\hline & Greek source & & Sergius's Syriac rendering & & Hunayn's Syriac rendering* \\
\hline [1] & 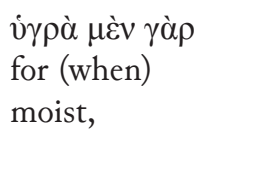 & $\rightarrow$ & 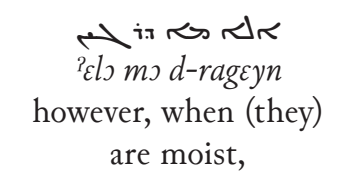 & $\rightarrow$ & 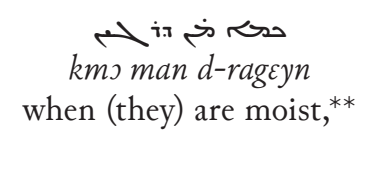 \\
\hline [2] & $\begin{array}{l}{ }^{(13)} \mu \tilde{\alpha} \lambda \lambda \mathrm{ov} \\
\dot{v} \pi \alpha ́ \gamma \varepsilon 1 \tau \dot{\eta} \nu \\
\gamma \alpha \sigma \tau \varepsilon \dot{\varepsilon} \rho, \\
\text { it discharges the } \\
\text { belly more, }\end{array}$ & $\rightarrow$ & 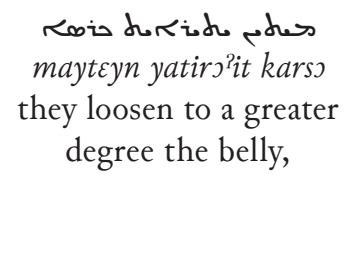 & $\rightarrow$ & $\begin{array}{c}\text { edes dorid odes } \\
\text { Koiv } \\
\text { maytsyu yatirs it maytsyn } \\
\text { karss } \\
\text { indeed to a greater degree } \\
\text { they loosen the belly, }\end{array}$ \\
\hline [3] & $\begin{array}{l}\xi \eta \rho \grave{~} \delta \\
\text { but (when) dry, }\end{array}$ & $\rightarrow$ & $\begin{array}{c}\text { ms d-yabišin deyn } \\
\text { but when (they) are dry, }\end{array}$ & $\rightarrow$ & $\begin{array}{c}\text { ms deyn d-yabišin } \\
\text { but when (they) are dry, }\end{array}$ \\
\hline [4] & $\begin{array}{l}\text { ï } \sigma \tau \eta \sigma \mathrm{l} \mu \tilde{\alpha} \lambda \lambda \mathrm{ov}, \\
\text { it stops (the } \\
\text { belly) more, }\end{array}$ & $\rightarrow$ & 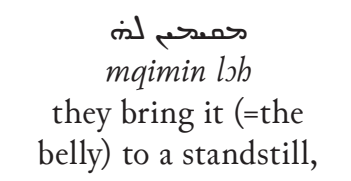 & $\rightarrow$ & 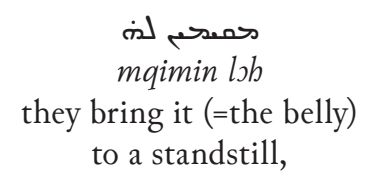 \\
\hline$[5]$ & 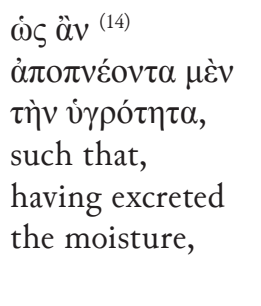 & $\rightarrow$ & 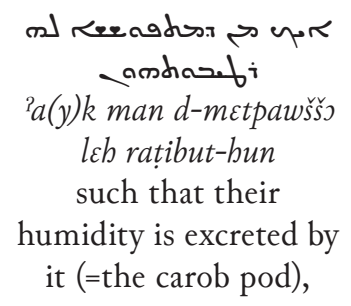 & $\rightarrow$ & 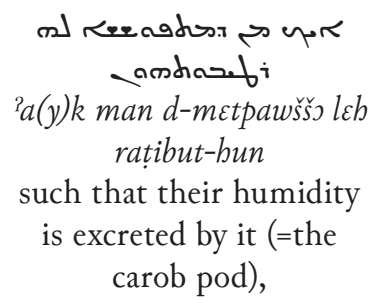 \\
\hline [6] & 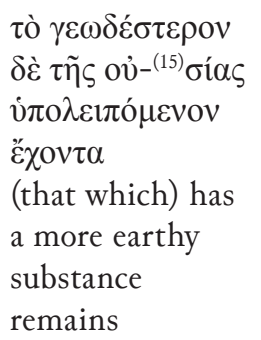 & $\rightarrow$ & 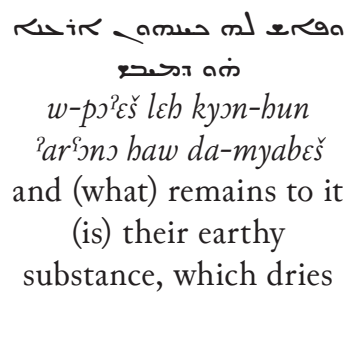 & $\rightarrow$ & 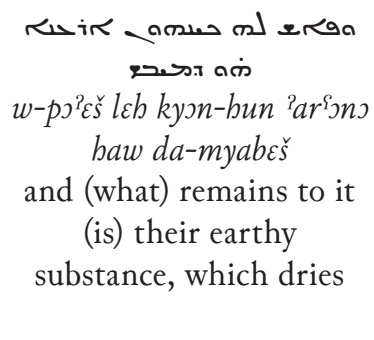 \\
\hline
\end{tabular}

* As per BnF syriaque 423 141r, lines 4-8; Mingana Syriac 594 127v, lines 9-13.

** See table 1 , note ${ }^{* *}$. 
well illustrated by the Syriac text of segments [4]-[6]. The length and grammatical complexity of the passage are sufficient to render it extremely unlikely that both Sergius and Hunayn somehow came up with exactly the same sixteen-word sequence independently. But the additional fact that Sergius's added explanatory gloss, הדבר, הaw da-myabeš (literally "that which dries"), at the end of segment [6], which is not present in the Greek source text, is also found in Hunayn's version, and it closes the case, so to speak, on this issue of Hunayn's dependence on Sergius's earlier version. Hunayn may well have consulted one or several Greek manuscripts of Galen's Simples when composing his version of this passage (indeed, other examples make it clear that he did do so), but in the case of segments [4]-[6] it is clear that Hunayn had not only also consulted Sergius's translation of this passage, but approved of it, and even adopted its wording verbatim in his own version. This first strategy, the so-called copy-paste method, is quite common in the corpus of parallel passages; a rough estimate suggests its presence in less than a third of the corpus. ${ }^{42}$

If Hunayn's first method may be characterized as a "copy-paste," then his second type of approach to Sergius's earlier version could be called an "edited copy-paste." Segments [1]-[3] of our passage provide several illustrations of this second method. In segment [1], for example, Sergius seems to have understood the Greek particle $\gamma$ ò $\rho$ in the first segment in a disjunctive way, since he used the disjunction $\nabla \kappa{ }^{2} \mathcal{E} l$ (but, except that). Hunayn chose instead not to render yò $\rho$ at all in his translation, but translates instead post-positive $\mu \grave{\varepsilon} v$ (which Sergius had ignored), which he renders with the related $^{43}$ Syriac particle, post-positive man. Finally, Hunayn replaced the subordinating conjunction $m s d$-, which means "when" with the slightly expanded form $k m o d$ - with the same meaning.

In segment [2], one can also recognize Sergius's version in Hunayn's, but again, it has been slightly edited. The Greek source text, for example, begins with an adverb, $\mu \tilde{\alpha} \lambda \lambda$ ov (more). Sergius had relegated the adverb to second position in his sentence, probably because it was simply stylistically and

42 We will present a more detailed statistical assessment in a forthcoming publication.

43 An early loanword from Greek into Syriac; see A. M. Butts, "Greek $\mu$ '́v in Early Syriac," Hugoye 16 (2013): 211-23. 
syntactically clearer in Syriac to begin with the verb (here the participle maytcyn [they bring in]). Hunayn retains the same participle, but pushes it back after the adverb yatirs? it (to a greater extent), and then adds another adverb up front- a cognate form of the verb, an infinitive here used "absolutely" as an adverbial intensifier. Hunayn thus ended up with a segment that has two sequential adverbial elements up front, followed by the verb, then finally the direct object, a syntactic structure that mirrors the Greek syntactic order. Thus, in segment [2] we have an example of Hunayn seeking to emulate the syntax of the Greek source text, much more than Sergius's version of this segment did.

Finally, in segment [3], Hunayn used the same words as Sergius, but changes their syntactic order slightly. He apparently disapproved of the post-positive particle deyn being positioned after the predicate adjective yabišin (are dry), whereas Sergius had no doubt chosen that particular syn-

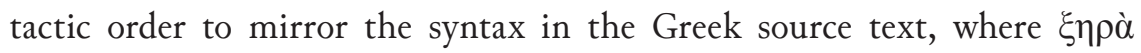
comes before, not after, the particle $\delta \varepsilon$.

Thus, if the rationale of the first method, the simple "copy-paste," seems perhaps to have been efficiency (that is, saving time), then it seems reasonable to imagine that that of the second translational strategy, the so-called edited copy-paste, was a compromise between saving time and providing Hunayn's target audience with a rendering that was more stylistically satisfying and idiomatic (at least, in the minds of ninth-century readers of Syriac in Baghdad). This second method appears to be the most common, perhaps roughly 40 percent, in the corpus of parallel passages.

Whether or not he indulged in editing of Sergius's existing version, neither did Hunayn limit himself to slavish dependence on Sergius's earlier work. This brings us to a third approach used by Hunayn when dealing with Sergius's earlier work: that of the "paraphrase." For purposes of illustration, a single example will here suffice, but like the two previously described methods, this "paraphrase" approach is also quite common within the full corpus of parallel passages, perhaps, like the "copy-paste" method, present in roughly 30 percent of the examples.

The illustration comes from another passage excerpted from Book 7 of Galen's Simples, again chapter 10 (plant names beginning with the letter 
TABLE 4. Sergius's sixth-century and Hunayn's ninth-century Syriac renderings of an extract from Galen’s Simples VII.10.37 (XII.34.4 Kühn).

\begin{tabular}{|c|c|c|c|c|}
\hline & Greek source & $\begin{array}{l}\text { Sergius's Syriac } \\
\text { rendering* }\end{array}$ & & Hunayn's Syriac rendering** \\
\hline [7] & 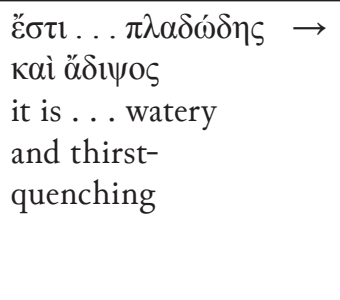 & $\begin{array}{c}\text { s... . mador } \\
\text { itawaso } \\
\text { wa-mpigsns } \\
\text { it is ... watery and } \\
\text { refreshing }\end{array}$ & $\rightarrow$ & 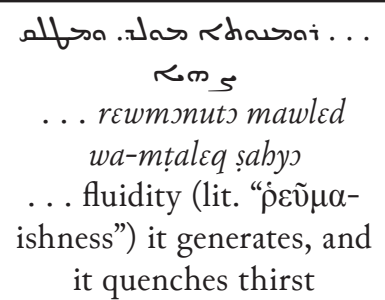 \\
\hline
\end{tabular}

* As per BL 42r, line 4; to our knowledge, the corresponding passage in SGP has not yet been identified (see R. Hawley, "More identifications" [cited above, note 43]:253; cf. the "skeleton table" in Afif et al., "Continuing research" [cited above, note 43]:267).

** As per BnF syriaque 423 111r, line 16 (ult.); Mingana Syriac 594 103r, lines 7-8.

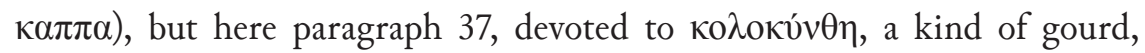
probably the "colocynth"44 (see table 4).

In passages such as this one, which exemplify this third approach, it is not evident that Hunayn made use of Sergius's version at all. Or rather, if he had consulted it (which seems likely given the frequency of the first two approaches), he must have subsequently dismissed it as unworthy of emulation. In these cases, Hunayn chose instead to paraphrase; he seems to have been interested not so much in the wording of the Greek source text, but instead in the meaning of the passage, expressed not with technical terms but instead with more familiar, banal, and idiomatic vocabulary.

It is also interesting to note that it was this third method that ended up becoming Hunayn's claim to fame in subsequent tradition. ${ }^{45}$ Even though

44 That is, from Simples 7.10.37 (and more specifically, Kühn XII.34,4).

45 The caricature presented by the fourteenth-century writer al-Ṣafadi is a well-known example, as translated by F. Rosenthal in The Classical Heritage in Islam (London: Routledge \& Kegan Paul, 1975), 17: “The . . method is that of Hunain ibn Ishāq. . . . Here the translator considers a whole sentence, ascertains its full meaning and then expresses it in Arabic with a sentence identical in meaning, without concern for the correspondence of individual words. 
he did in actual practice make extensive use of the "copy-paste" method, and even though he did sometimes rearrange or slightly edit Sergius's earlier translation (sometimes apparently in order to make the resulting translation more literal or syntactically closer to the Greek source), despite these two considerations it is interesting that later tradition would nevertheless best remember Hunayn as the great paraphraser.

\section{Conclusions and Perspectives}

This short survey was intended to highlight two types of data present in the Syriac versions of Galen's Simples that make them important for future research. The first has to do with the importance of the earliest (and probably very first) Syriac version, that of Sergius of Reš 'Aynā, not only for the study of Syriac medicine, but also and especially for its role as a very early indirect witness to the Greek text of Galen in circulation in the late antique Near East. A single, striking example was presented here, and several others will be made available shortly. ${ }^{46}$ The Syriac material assumes an even greater importance, since a critical edition of the Greek text of Galen's Simples is currently in preparation.

The second group of examples confronts the sixth-century Syriac translation of Sergius with the ninth-century one attributed to Hunayn ibn Ishāq and his school, through a small but instructive corpus of around thirty parallel passages. Here, also, research is currently under way, but once published, the results promise to offer important new insights for understanding the mechanics of how Syriac translation technique developed between these three critical centuries. Especially important is the possibility provided by this corpus of parallel fragments of confronting, on

This method is superior, and hence there is no need to improve the works of Hunain ibn Ishāq." For a critique of this view, as owing "more to an elegant idea than to concrete reality," see Pormann, "The Development of Translation Techniques," 148 (and note also pages 14446 , for a brief and well-documented history of the discussion); cf. also R. Hawley, "Three Fragments of Antyllus," 254.

46 See note 8 . 
the one hand, what can be known about the history of Syriac translation technique from traditional literary sources, with, on the other, the analysis of actual textual data drawn from parallel passages. Of course, the discrepancies that emerge from such a confrontation are interesting, ${ }^{47}$ but the points of agreement are equally interesting.

In regard to this latter point, for example, it is tempting to find traces of Hunayn's three methods of dealing with Sergius's text, as outlined above, in his own autobiographical description of his work with the entire Galenic corpus. The relevance of the first method (the "copy-paste") is suggested by the fact that Hunayn had direct knowledge of Sergius's version, and by the fact that he was commissioned by a patron to produce another (ostensibly improved) Syriac version. The mere existence of clear examples of the "copypaste" method shows clearly that expediency sometimes outweighed assiduity as Hunayn dealt with the Sergius's existing text: some shortcuts were inevitably taken, a reality that should perhaps come as no surprise given the length and difficulty of the task at hand. Second, the explicit mention that a member of the Māsawayh family asked (or commissioned) Hunayn to attempt to improve ${ }^{48}$ Sergius's Syriac translation seems to be an echo of the second method described above (the so-called edited copy-paste). The final proviso, to the effect that it would have been better for Hunayn to translate this entire second part of Galen's Simples anew, ${ }^{49}$ seems to make allusion to the third and final method described above, that of the paraphrase. Be that as it may, the very existence of numerous passages that illustrate the first two methods amply illustrates just how much Sergius's translations had remained of fundamental importance to Syriac and other intellectuals interested in Galenic medicine, even three centuries after his death.

47 See above, segment [7], and the minor differences observable in segments [1]-[3].

48 According to Hunayn, wa-sa'alanî. . 'iṣlāba-bu, "and he [=] requested of me . . its improvement”; see Lamoreaux, Hunayn ibn Ishāa q, 68-69.

49 Again according to Hunayn, 'alâ 'anna l-'aṣlạ̣a kāna tarğamatu-bu (it would have been better to translate it [afresh])"; see Lamoreaux, Hunayn ibn Ishāq, 68-69. 